\title{
An anthropological approach to HEPPs in Eastern Anatolia: The case of Aksu Valley
}

\author{
Pervin Yanikkaya Aydemir \\ Master's Degree Program, Yeditepe University, Anthropology Department, Istanbul-Turkey
}

Email address:

pya.aydemir@gmail.com

\section{To cite this article:}

Pervin Yanikkaya Aydemir. An Anthropological Approach to HEPPs in Eastern Anatolia: The Case of Aksu Valley. Journal of Water Resources and Ocean Science. Vol. 2, No. 5, 2013, pp. 115-124. doi: 10.11648/j.wros.20130205.19

\begin{abstract}
Both water and development have very important functions in human life. Throughout the history, people have designed and constructed dams, reservoirs and irrigation systems to supply agricultural lands with water as well as converting water into energy as part of development projects. While water resources development projects are mostly preferred as they are cheaper and clean compared to other alternatives, impacts of such projects on people, their livelihoods and nature have been particularly devastating in many parts of the world such as Asia, Africa and Latin America. Recently, with an argument of increasing energy demand and reduction in dependence on imported energy, Turkish government has initiated some sort of "mobilization" for small hydroelectric power plants (HEPPs) to be run by private companies, particulary in the Eastern Anatolia and Black Sea regions. Despite recent initiatives, there is no established water policy in Turkey. Outsourcing control over free-flowing streams out of local representational structures into the hands of private companies has resulted in social movements and protests against these projects. I conducted a fieldwork in one of the valleys in Eastern Anatolia where two HEPPs have been constructed. Methods used during the 8-week fieldwork included participant observation, focus group studies and in-depth interviews. Privatization of the water resource in the Aksu Valley (formerly Salaçor) not only gave the entire control of water to the contractor company for 49 years, but also left all the public services in the valley to the mercy of the company while use of water has been historically well-managed by the local community, who was in control and distribution of the water. This paper discusses outcomes of the HEPP project in daily life of the local people in Aksu Valley, asserting that users of water resources should have been considered as participants in water management, planning, and decision-making of development projects. A drop of water is a sea to an ant, Afghan proverb
\end{abstract}

Keywords: Anthropology, Water, Development, HEPPs, Eastern Anatolia

\section{Introduction}

Development is indispensable, so is water. It is apodeictic that both have very important functions in human life in relation to natural, cultural, spatial, temporal, physical, symbolic, artistic and ideational landscapes. However, the mutual relationship between development and water may have both negative and positive outcomes depending on their convergence. Lundquist and Gleick indicate that "Lack of water is a barrier to sustainable socioeconomic development; lack of development is a barrier to solving water problems. Because water integrates so many aspects of life, it must be given primer consideration in the context of development objectives. This includes the day-to-day management of water, decisions about allocations for socioeconomic activities, and the preservation of natural resource capital" [1].

At present, globalization and development are usually used interchangeably. As a post-World-War II phenomenon, globalization is associated with the emergence of development, where both have their roots in colonial histories [2]. Since many of the definitions of globalization feature mainly economic aspects, Ted Lewellen, with an attempt to make an anthropological definition of globalization, proposes that "Contemporary globalization is the increasing flow of trade, finance, culture, ideas, and people brought about by the sophisticated technology of communications and travel and by the worldwide spread of neoliberal capitalism and it is the local and regional adaptations to and resistances against these flows." [3]. Even though anthropologists did not see development as one of their areas of major interest, they often made 
assumptions in their ethnographies. Accordingly, Lewellen argues that globalization represents a significant break with traditional anthropology since "traditional anthropology looked at bounded cultures and communities" whereas "globalization theorists are more likely to be interested in transnationals, diasporas, nations that are scattered in many countries, and deterritorialized ethnicities.".Anthropology is not about isolated people living in distant and exotic places anymore, but about plurality and diversity of people who are made to be part of a universal world as bounded to each other in a dynamic and interactive way by means of various globalization processes. Accordingly, as countries of the world and their people have been tied into the global economy since 1960s, anthropologists as well as other social scientists, are becoming more concerned with the impact of globalization in social and environmental policies [4].While optimization of human adaptation and maintenance of ecosytems were primary concerns of cultural practices, new ecological or environmental anthropology blends theory with political awareness and policy concerns[5].The political and economic interconnectedness in the global world alters local ethnoecologies by challenging, transforming, and replacing them.

\section{Environment and Anthropology}

Since the earliest days of the discipline, anthropologists are interested in questioning how people modify, symbolize and adapt to their immediate environment. According to Edelman and Haugerud,in the 1970s anthropologists were under the influence of dependency and world-system theories, peasant studies and feminism, and their focus was centered on culture-political economy [6]. By the mid-80s, there was an important shift and anthropologists started to avoid systematic analyses of political economy and the new economic liberalism which favors fragmentary attacks on economic reductionism and cultural essentialism. In the 1990s, there were only a few anthropologists who resisted neoliberal arguments, favoring free markets in decisionmaking rather than governments while the opposite was also untrue, and preference of the late 20th century anthropology to focus on "flux and fragmentation rather than powerful economic actors perhaps reflected anthropology's traditional focus on small-scale phenomena". Similarly, economic policies and everyday politics are not among the points of interest of anthropological studies of the environment and resource conservation, which mainly focus on indigenous rights and social aspects of the nature. However, nature has always been one of the central concerns of anthropology, "whether in the field of folk-sciences and cultural ecology or in the study of myths and rituals linked to the environment and subsistence systems" [7].

Okongwu and Mencher argue that anthropologists have written mainly for other anthropologists, "not for those who have the power to change the world", and in reaction to this trend, some anthropologists pointed out the importance of anthropology moving to shape public policy and assist in formulating the critical issues of the society by proposing solutions that meet the desires and needs of local people, and creating a synergy between theory and practice [4]. Political positioning is inevitable in the production of anthropological knowledge since we became "aware of the profound political implications of seemingly objective forms of knowledge" [8]. In the meantime, in response to changing circumstances, a new ethnoecological model has emerged: sustainable development, which aims at culturally appropriate, ecologically sensitive, self-regenerating change. It became a very popular approach in planning and development projects, however there are only few examples of successful sustainable development projects [5] due to several reasons such as multiple definitions and interpretations of sustainability, lack of an integrated approach, lack of community involvement, lack of effective monitoring and evaluation, co-operative governance unsupportive of effective sustainable development, and unsustainable rising levels of natural resource abuse as outlined by Nealer and Naude [9]. Each of these problems experienced with sustainable development eventually intersects with multiple domains of anthropology,in one way or another. And, water is one of the main components of sustainable development and environmental issues.

\section{Water and Anthropology}

Water, as a basic human right, has become a compelling theme in anthropology due to scarcity all over the world. For anthropologists, it is not only a resource, but a substance connecting many realms of social life to study different forms of valuing water, unequal distribution of water, rules and institutions that govern water use and shape water politics and knowledge systems of water [10]. However, there is a need for a broader understanding of water as suggested by Blatter et al. [11] who emphasized the significance of 'renewed awareness of natural imperatives' and 'multiple meanings of water bound to various cultures' as an expansion to legal, technical and economic definitions of water. Focusing on connectivity and materiality aspects of water, Orlove and Caton suggest five principal themes for studying connectivity of water by anthropology: value (natural resources and human rights, equity (access and distribution), governance (organization and rules), politics (discourse and conflict) and knowledge (local/indigenous and scientific systems), and they conclude that 'waterworlds' must be studied ethnographically including all components such as 'waterscapes', 'watersheds' and 'water regimes' in connection to science and technology studies as well as maintaining connections with political ecology and material culture studies [10], particularly given the degeneration of sustainability of water into a political and ecological chaos due to its potentiality as a hydropower.

As a hydropower, water has been one of the essential 
renewable energy resources. Throughout the history, human kind have designed and constructed dams, reservoirs and irrigation systems to supply agricultural lands with water as well as converting water into energy as part of development projects for modernization. The water resources development (WRD) projects are favored because they produce relatively clean energy besides being a cheaper option to invest and operate. However, these projects have pros and cons: on one hand, urban dwellers enjoy the availability of electricity; industries increase their productivity and create more jobs for workers; and farmers cultivate double or more crops resulting in increased agricultural production, on the other hand they create socioeconomic, cultural, psychological, ecological, even health problems in people living in the immediate environment of the constructions [12]. In modern times, we are all familiar with the most dramatic effect of large dams that were built all over the world resulting in relocation of 40-80 million people, mostly indigenous, tribal and peasant communities, from their lands in the past six decades as indicated by the World Commission on Dams [13]. The impacts of dam building on people and livelihoods have been particularly devastating in Asia, Africa and Latin America.

Unfortunately, through globalization and implementation of neoliberal policies, privatization of water resources takes the control of water from local communities and gives it to a small group of people and does not include all legitimate actors in decision-making processes although it has been recognized that "involvement of users and sharing of responsibilities and management tasks is a prerequisite for proper choice of technological and organizational approaches" [1]. Management of water not only as an economic entity, but a social entity, requires social participation. This participation should be democratized in the short and long runs, where democratization of participation will aim, in the short run, "to improve information flow and introduce realizations about the political dimensions of social participation" while in the long run, democratization of participation will aim "to promoteregulation of asymmetrical powers" [14]. The most effective water policies and institutions are those who involve users of water as participants in water management, planning, and decision-making. With experience, it has become clear that major decisions made without involving local communities and those affected by these decisions are more likely to fail. For example, Veronica Strang points out that "the process of centralisation, enlargement and alienation, compounded by the recent privatisation of the industry, has perceptually severed the ties between most people and water resources", leading to anxiety and anger of local people in Stour Valley, Dorset "since they feel that 'their' most vital substance is in the hands of a highly untrustworthy 'other" [15]. The impact of globalization and privatization of natural resources has been extensively studied and selected $(16,6,2,17)$. Outsourcing the resource control to the 'highly untrustworthy other' while excluding local communities from the regulatory processes severely damage the notion of water as a collective good that has been well-managed so far by social agreements, and unmask the political actors acting on behalf of the international capital. The experience is no different in Turkey.

\section{Water and Turkey}

Turkey has a surface water gross production of 193 billion $\mathrm{m}^{3}$. Fifty-eight percent of this gross potential represents usable water potential, where annually usable amount of water per capita is $1430 \mathrm{~m}^{3}$ making Turkey one of those countries with water stress. It is a known fact that with an estimated population of 100 million in 2030, Turkey will become one of those water-poor countries, with an annually usable amount of water per capita of $1000 \mathrm{~m}^{3}$ [18]. Turkey, surrounded by waters on three sides, has a coastline of $8300 \mathrm{~km}$, and a total land area of $779452 \mathrm{~km}^{2}$, of which $98.17 \%$ comprising land, and $1.83 \%$ water. At present, there are 230 finished dams in Turkey. Consumption of water for drinking, irrigation and industry is $15 \%, 75 \%$ and $10 \%$, respectively.

Although water is a public propertyall over the world and water resources are mainly managed by public institutions (99\% in Asian, 97\% in African, 96\% in Central and East European, $95 \%$ in North American and $80 \%$ in Western European countries) [18], at present Turkey has adopted an aggressive commodification and privatization process for water services. The public aspect of water has been lost to a private and profitable commodity through legal mechanisms, which gradually render national and local organizations legally responsible from drinking, utility and irrigation waters into inactive entities such as General Directorate of State Hydraulic Works (DSI), General Directorate of Rural Services (KHGM, already shut down), General Directorate of Electric Power Resources Survey and Development Administration (EIE), and the Bank of Provinces. However, it has been shown that decreasing investment, operation and control power of the public sector in favour of private sector leads to several problems in planning, control and environment [19]. Lack of effective planning and appropriate mechanisms for monitoring and surveillance presents further legal and environmental issues. Tekiner Kaya argues that it is, in fact, the lack of legal environmental regulations and inappropriate implementation of law for nature protection, which are directly reflected in both operational and initial investment costs that make hydroelectric energy cheaper in Turkey [20].

Turkey's recent energy policy is established around two main arguments; "increased energy demand" and "dependence on imported energy". With a focus mainly on management of supply rather than management of demand, the policy encourages energy production as much as possible while efficient use of energy is considered to be of secondary importance [21]. Like many other developing 
countries, Turkey also wants to make use of its energy resources at best in order to meet increasing demands of a rapidly rising population as well as reducing reliance on external financing and energy sources. Following the enactment of the Electricity Market Law No. 4628 on 20.02.2001, the Energy Market Regulatory Board of Turkey (EPDK) allowed private sector companies to build, generate, operate and distribute electricity by liberalising the market. This law paved the way for many national and international energy or irrelevant companies to scramble, particularly for renewable energy investments. Due to a potential hydroelectric power capacity of 130 billion $\mathrm{kWh} /$ year [22], use of water for many streams in Anatolia has been contracted to private companies for 49 years, rendering it into a benefit-loss economy. According to the 2012 Report of Union of Chambers of Turkish Engineers and Architects [23] on Hydroelectric Power Plants (HEPPs), at present there is a total of 1941 projects for river-type HEPPs; 205 already operating, 514 being constructed, and 1222 with a ready research and master plan (Table 1). Furthermore, projects for 10000 micro power plants have been in progress (Fig. 1).

Table 1. Development of Hydroelectric Power Production in Turkey

\begin{tabular}{lcc}
\hline Status & Quantity & Installed Capacity (MW) \\
\hline In Operation & 205 & $14.405,24$ \\
Construction Phase & 514 & $14.098,52$ \\
Provincial Administration Survey, Master Plan, Planning and Final Design Ready & 1222 & $47.067,34$ \\
Grand Total & 1.941 & 1215 \\
Developed by Legal Entities Inside Grand Total & 259 & 5.360 \\
Projects Developed by DSİ and EİE According to Article 4628 inside Grand Total & 2571,10 \\
\hline
\end{tabular}

Source: TMMOB Hydroelectric Power Plants Report 2011

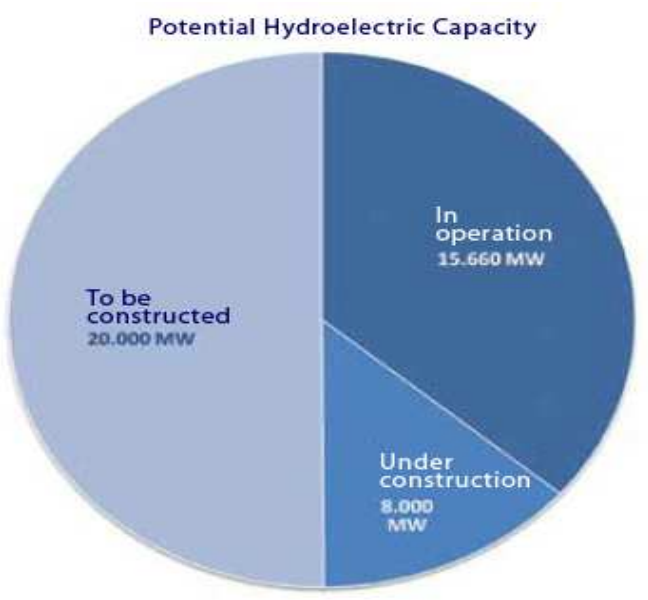

Figure 1. Potential Hydroelectric Capacity, Source: TMOBB Report 2011

\section{Management of Hydroelectric Power Plant Projects in Turkey}

Mostly, inelaborate feasibility, planning and localization of HEPPs result in juridical cancellation of many projects in most environmentally vulnerable regions. One of the major issues is flow requirements. Most of the projects promote release of only $10 \%$ of the average instream flow. The 2001 TMMOB Report indicates that EIA reports have serious scientific and technical problems as they are mostly prepared by 'copy-and-paste' technique. Even engineers who are in support of HEPP projects criticize planning and surveillance stages of these plants [24]. Social participation is not encouraged, and for projects under $25 \mathrm{MW}$, local people are totally ignored while meetings held by the contractors for projects over $25 \mathrm{MW}$ are usually nonfunctional [21]. In a survey with 90 people in Artvin for the present and planned dams and HEPPs on the Çoruh River, major negative outcomes listed by the local people included damage to green life, agricultural products, and culture by $50 \%, 33 \%$, and $33 \%$ respectively while positive outcomes included changes in the regional climate, new job opportunities for local people and economic recovery by $22 \%, 15 \%$ and $8 \%$, respectively [25]. As concluded in a parallel report by several NGOs for submission to the UN Commission, "The dams in the Çoruh Valley violate the right to an adequate standard of living in many respects." [26].

It has been reported by Özalp et al. that the government planned to build 15 large dams on the main channel of the Çoruh River Watershed, and 116 small HEPPs on the tributaries of the river, which are likely to disturb forests, water and soil during construction works due to steepness and roughness of the terrain in the region as well as serious damaging in riverine habitats, riparian zone vegetation, accelerated soil erosion and sedimentation problems due to changes and derivations of the river channel's water regime [27].

Inevitably, privatization of water resources and intrusions in many unheard valleys led to social movements and protests against these projects. Local people from these valleys gathered around a movement called "Anadoluyu Vermiyoruz/We Will Not Surrender Anatolia", and organized a nation-wide walk in January 2011 towards Ankara, the capital city of Turkey from all geographic regions under the threat of HEPP projects, but the walk was 
blocked by security forces, and they were not allowed to enter the city and visit the National Assembly [28]. While these protests are still going on mainly on local-basis, and rarely in big cities with the participation of locals and activist groups, both the local protestor and the activistprotestor struggle against the same water policy, i.e. the global capitalism, that, in fact, makes it a global class struggle, and thus these protests shouldn't be considered only as local ecological movements [29]. However, the contractors do not give up, and either through illegal ways or exploitation of legal gaps, they continue their construction activities with an 'intimate help' from the government by enactment of an expedited expropriation for energy projects.

Although it is believed that construction of a small HEPP does not necessarily require any change in the structure of the community, it, in fact, has a strong impact in power relations, daily-life settings, gendered economic activities, social activities, interpersonal relationships, etc. While administrators and some people from the local community may see this construction as a service and benefit to their daily life, some others may not favour such a radical change and disturbance in their daily life. This was exactly what happened in the Aksu Valley. While the site offers a variety of topics, each to be discussed elsewhere in detail such as 'extermination' of peasantry and subsistenceagriculture, intervention in a well-functioning hydrosocial circulation, impact of privatization on natural resources and destruction of ecosystems, strong formation of national and ethnic identity with respect to geography, social and cultural changes, role of religion and hegemonic power in social change, gendered activities, local architecture, toponymy, foods, etc., below you will find a story about how a valley has been appropriated politically by construction of two HEPPs to legitimize a variety of neoliberal practices in the name of energy development as a vivid example of 'neo-colonialism'.

\section{Aksu Valley}

Aksu Valley is located in the Eastern Anatolia. It is within the borders of Ispir, one of the northern districts of Erzurum. It has a transitional climate between the Eastern Black Sea Region and the East Anatolia. It is $163 \mathrm{~km}$ far from the Province of Erzurum, and $20 \mathrm{~km}$ from the District of Ispir. It is a green valley starting from the 20 th $\mathrm{km}$ of Ispir - Artvin road that runs alongside the Çoruh River, and extending to the borderline of Hemşin District of Rize Province up toan altitude of approximately $1000 \mathrm{~m}$. After the $35 \mathrm{th} \mathrm{km}$, it rises to an altitude of $3711 \mathrm{~m}$ where the Verçenik Hill is one of the peaks of the renowned Kaçkar Mountains [30].

There are four villages in the Aksu Valley: Aksu, Yedigöl, Çatakkaya, and Yildıztepe. Aksu Village has 13 quarters scattered around both banks of the streambed.The houses typical to this region with metal roofs were built on the rock slopes. Aksu, formerly Salaçor, is a very narrow valley breached by the Aksu Stream, and the major basis for subsistence in the valley is horticultural products, particularly 'İspir bean' grown in an area of ca. $950.000 \mathrm{~m}^{2}$ wheremost of it have been created out of nothing by local people through terracing, filled with soil carried on their back. So, the soil is not thick enough to retain water, that's why it needs frequent irrigation. Another major basis for subsistence is mulberries. Most of the people earn money from mulberry molasses. Apiculture is also a common source of subsistence with a production of approximately 20 tons/year. It is an organic valley since all crops are raised using animal manure and green manure not as part of a current trend, but traditional agricultural methods maintained for hundreds of years. Animal husbandry and dairy products are the main source of income for villages and quarters in the higher parts of the valley. With an ideal climate and water, the valley is also suitable for pisciculture. There is only one trout farm at present.

It is under the influence of Black Sea region climate. The weather is not too warm in the summer or too cold in the winter. It is home to various endangered animal species; mainly eurasian otter, chamois, black spotted wildcat, red speckled trout, wild goat, and grizzly bear. Organically grown apples, wild cherries, wild pears are among the fruits that grow in the area as well as walnut, hazelnut, hawthorn, hibiscus and linden trees. It was announced as a "Wild Life Development Area" by the Ministry of Environment and Forestry in 2004 [30]. To emphasize the natural uniqueness of their homeland, locals make a wonderful description of the valley; "It is an extraordinary place in which cherries blossom down in the valley when snowdrops (galanthus) flourish in the higher parts". The locals, men or women, even children know all the plants, animals and physical resources in their environment, and appreciate their value.

The population of valley varies depending on the season, from 450 people in winter up to 2000 people in summer. All of the inhabitants are related to each other, in one way or another, either from mother's side or father's side, sometimes even from both side. The valley had a selfsufficient population until 1970s when some men went to big cities to seek for a job because of sources that fell short with increasing population. After a while, some were followed by their immediate families. Now, most of the families have two homelands; 'place of birth' and 'place of breadwinning'. Majority of the people live in big cities, mostly engaged in bakery. The District of İspir is renown with its bakers across the country, so through relations they have easy access to such jobs. Some locals work at seasonal jobs, and return to the valley for summer. There is an in-betweenness of village and urban life reflecting itself in a complex relationship to modernity.

I conducted a fieldwork in the valley in the summer of 2012 for eight weeks to collect data for my master's thesis, which is about the impact of HEPP projects on daily life of local people living nearby. During my stay, in addition to participant observation, I conducted focus group studies and in-depth interviews with locals. I was very nicely 
welcome by the villagers, and they seemed to be happy to have someone living with them and sharing their experience. They had a lot to say, but they had serious trust issues, so did I. A few avoided participating in focus groups or interviews while some others seemed very enthusiastic about talking. This paper aims to give an overall picture of their experiences in relation to changes in daily life as a result of HEPP construction in their valley.

\section{Hydroelectric Power Plants and their Impacts in the Valley}

At present, there are two hydroelectric power plants in the $35-\mathrm{km}$ long valley, and three other projects are on the way, as well as a dam project, which will flood the Dereağzı quarter located at the convergence of Aksu Stream with the Çoruh River. The two plants have been operated by Borusan EnBW Energy, which is a partnership between Borusan Group, one of the leading Turkish holdings engaged in steel, distributorship (BMW), logistics and energy industries, and EnBW Holding Ag, one of the leading energy companies in Germany. Two plants have an installed capacity of $50 \mathrm{MW}$, composed of 2 regulators, 2 tunnels, 2 powerhouses and switchyard facilities [31]. The Yedigöl plant started to operate in October 2011 while Aksu plant was not operating when I was in the valley. The immediate impact area of these two plants included four quarters, namely Kadıbağı, Massırdap (Yolbilen), Gılok (Otluca) and Dereağzı.

As well said by Jamie Linton, it is difficult to write, talk, and even think about water without involving people in the story, and "the state of water always reflects, in one way or another, the state of society." [32]. For local people, the Aksu Stream was the source of life and joy until huge construction machines and crowded workforce appeared at the confluence of their stream with the Çoruh River five years ago. Nobody knew why they came for. Neither official authorities nor the contractor company had organized a public consultation meeting before initiating construction activities. At first, the villagers were told that they were there to enlarge the road, and thus they were gladly welcome. However, after a while, it turned out that these machines and workforce were, in fact, part of a different agenda, which became evident day by day with dynamite explosions, thousands of cut trees, day-and-night traffic of hundreds of trucks and land-rovers, thick depositions of dust on trees, growing plants and crops, windows and interior of houses, hundreds of dying red speckled trouts, alterations to the stream bed, cloudy stream water and irrigation water, discharge of waste waters directly to the stream, towering piles of debris on the lands or in the stream, damages to the road and overall landscape, damages to the graveyards, rolling rocks from the hills, gradual elevations in the road, and making wild animals, particularly wild goats easier targets for hunters with a few unnatural pathways at certain points, etc. Such negative events experienced in a cascading manner during the construction process were immediately reflected in inhabitants' quality of life, putting them into a sociological and psychological stress. The sociopsychological benefits they enjoyed living in a stable and isolated environment such as certainty, familiarity and comfort, and most importantly, their vital source, the Aksu Stream, and its environs suddenly had become under the threat of an energy project. They were about to lose the sound of the stream they were born into! Things were not what they used to be anymore in their landscape.

The threat induced by bulldozers into their life space and scenery resulted in complaints by the villagerswho developed anxiety and anger against the idea of losing their homeland, but they found nobody to direct their complaints. The official authorities did not pay attention to their questions while the contractor turned to a deaf ear. As a result, a few individual protests turned into a community action against the construction activities with an aim to protect and defend their living space. As Clifford Geertz argues, environment is an active and central factor in shaping social life, and "an established society is the end point of such a long history of adaptation to its environment that it has, as it were, made of that environment a dimension of itself" [33]. It was very unusual for these native people, who call themselves "Dadaș" to resist because they are renown with their strong nationalist feelings, and being Dadaş is identified with braveness, courageousness, fairness and chivalrousness. While they still feel uncomfortable to have shown disobedience and resistance to the authority, they say that they are always proud of being loyal to the state and obeying the authority, but, due to the threats to their living space accompanied with fear of loss of their land and possibility of relocation, they had nothing to do, but resist. One of the most common characteristics is that they are proud of never being a burden on the state, and they all tell the story about their grandparents who did not abandon their land and fought against the Russian army when Ottoman soldiers retreated from the region at the beginning of World War I. At that time, there was also an Armenian community living in the valley. Although officially changed, local people still use Armenian names of some quarters.

They also talk proudly about being able to collectively finance all public services by their own resources for years. For example, they indicate that they used their own collective resources to build the potable water pipeline from springs feeding the Aksu Stream, mosques in some of the quarters, the schools, the village clinic and a house for the midwife, the leisure rooms in each quarter, side roads to quarters, bridges over the stream and many other public services. They indicate the state was only involved in the construction of the once-a-stabilized road running alongside the stream, which was completed within a period of 13 years during governance of different governments. 


\section{Protests and Disrupted Social Order}

Their resistance and protests became organized with the help of the Wildlife Conservation Society of Aksu Valley, which became active after arrival of the contractor in the valley. The activities of the Society representing all inhabitants of the valley are financially supported by the rich 'expatriate' people of the valley who live in big cities as well as membership fees. For a while later, their protests called attention of environmental activists, who supported protests against the HEPP projects across the country. The Society organized events in and outside the valley with their participation. Some of these events had widespread media coverage. For example, in a protest organized in İstanbul in November 2010, protestors involving local people of Aksu (both from 'place of birth' and 'place of breadwinning') and activitists wore masks of Boldoroz as a cultural symbol of a water monster narrated by the local people to keep their children away from the stream, and held a demonstration in front of a concert house where Borusan Quartet was giving a concert [34]. They had banners like; "Borusan, a friend of art and nature, destroys the nature of Aksu Valley", "Killer Borusan, get out of Aksu!", and "They dry out our streams, they kill our fishes; revolt!" accompanied with photographs showing the damages to the nature and graves in the valley. The company rejected these claims, and declared that they were acting within legal limits of their contract, respecting the life and expectations of the local people. Initially such protests had a broad repercussion in written and visual media. Many national and regional TV channels, reporters, and academicians visited the site to make the voice of Aksu people heard across the country and support their reactions. However, after a while the mainstream media stopped broadcasting about the protests against HEPP projects throughout the country as if the public dissent was squelched by invisible forces.

Despite so many efforts, nothing changed in the Aksu Valley. Whenever local people protested and tried to prevent contractor's activities, they found gendarmerie standing against them whereas they were expecting the gendarmerie to be on their side against improper working conditions of the contractor that threatened and changed their daily life. During interviews, they all mentioned that this was a real disappointment for them, particularly given the fact that gendarmerie has a particular place in daily life of rural people because their 'sons' also become gendarmerie when they serve in the army, so each Mehmetçik is everybody's son. Frequent confrontations with gendarmerie and their negative approach to the demands of the local people resulted in loss of trust and respect in this institution as well as the state itself.

In the meantime, the villagers became aware of the fact that the contractor started to win some of the villagers and protestors over, sometimes with money, sometimes by giving away some construction material like pipes, cement, etc., and sometimes by hiring them, which unsurprisingly resulted in conflicts among the local people. From then on, they started to engage in never ending discussions, arguments, and disputes, sometimes in loud outcries. Finally, when they found themselves alone with the contractor as 'orphans', in their words, feeling deserted by the state, some regretted to have been resisted to the contractor and the government by actively participating in protests, and believed that if they would have started negotiating with the contractor at the beginning, they might have been getting some benefit, while some others felt very disappointed with the outcome, and had two minds as to whether or not to move from the valley. At present, local authorities point the contractor for any public request made by the villagers, impelling them to become good negotiators with the contractor. When I was in the valley, the construction work was over, and the contractor was running one of the plants with a work force of 40 people, where 22 of them were hired from the Aksu Valley. The villagers told that these people preferred to work for the contractor although wealthy people of the valley offered them jobs with better conditions in other cities while the workers justify their preference stating that although they earn less, they are staying with their family, and taking care of their house, children, and crops. Although ultimately everybody made peace with each other, protestors still feel resent, and try to develop empathy with these 'traitors'.

No immediate impact was observed in the irrigation system. At present, the irrigation is carried out by conveying water from the stream through a number of ditches and using these ditches in a collective way in order. When someone finishes irrigating his/her (it is usually women doing these works) piece of land, s(he) puts the stone back to its place by the ditch to block the flow of water, and the neighbour starts irrigating his/her land. Since they usually know when and who is irrigating and see each other all the time, there is no flaw in the system. No disputes and no fights. Everybody knows what and when to do! The water is socially well controlled and regulated. Practice of collaborative use of these ditches forms sort ofa 'hydrosocial cycle' $[35,32]$ within the valley, water shaping the culture and vice versa. In addition to being a source of their irrigation system, water is an inherent part of their daily life. Children (only boys) play, swim and catch fish in the stream; women and girls spend almost every day outside nearby the stream, irrigating, gardening, picking vegetables and fruits (particularly mulberries every morning from June to September), chatting, sometimes eating, and setting fire in their courtyard or near the stream under cauldrons to cook mulberry molasses ('pekmez'), which is a main source of subsistence for many of them; and retired and older men sitting all day longin the gazeboslocated mostly on the streamside, accompanied with young and working men during their resting hours, chatting and drinking tea, even eating while enjoying the view.

However, the contractor designed and installed a new irrigation system in the valley, which was on trial when I 
was there. The jerry-built system did not look promising when relatively complex use of physically demanding pipeline valves is considered. Claimed to be a favour to the people of valley by the contractor, it rather seems to be a sign of complete control of the stream in the future. Most probably, none of the villagers will be able to use existing ditches and/or excavate new ones to divert water from the stream to his/her land anymore. Although the contractor argues that the new system, which replaces ditches with contractor's pipes, will be more productive and efficient, everybody I talked had hesitations, expecting potential problems and disputes over irrigation next summer. This hesitation, in fact, is doubled by another fact, that is, the ecological amount of water that will be left to the stream for living organisms and irrigation ('cansuyu' in Turkish). When they went to the court, the villagers were only able to increase it from an average of $200 \mathrm{lt} / \mathrm{sec}$ to $830 \mathrm{lt} / \mathrm{sec}$. They are very much concerned about the potential outcomes of reduced quantity of water including damage to their livelihoods, environment, biodiversity, natural food sources such as fish (already drastically reduced), crops, etc. The disturbed integrity of the stream is very likely to vindicate their concerns.

To their surprise, one issue that was well received and accepted by the contractor was placement of the poles for energy transmission line higher than it was planned. Interestingly, in the project the valley was shown as a moor without any settlement and inhabitants like many other valleys with a prospective HEPP project. It seems that what hurt local people most was to be regarded as "no one" in the official documents, but they remind that politicians will remember their existence when it comes to elections. This can be regarded as a sign of political awareness, in a way, referring to the strong relationship between water and power because now through the construction of a HEPP and an embedded intrusive contractor, the state became visible in their isolated living space, and acquired reality in their daily life whereas up until now it was mostly something to be confronted only when they went to İspir, the district center, to deal with a couple of official formalities, and when they used voting boxes.

It was upsetting to see that relationships among neighbours, relatives, and people living in other quarters had been all corrupted mainly because the contractor played them off against each other. Lack of trust to local and foreigner others was evident. Although almost all of them are related to each other, some people who had some benefit from the contractor seemed to have been ignored and isolated. Backbiting was common. Everybody said something behind others' back regarding their relationship with the contractor. I was also approached very cautiously by some locals unlike well-known traditional Turkish hospitality because of their preoccupation with what if I was a disguised contractor employee or a government official. I was explicitly asked a few times if I had some sort of a connection with the contractor.

$\mathrm{Be}$ it a woman or a man, they were very eager to talk about water whenever I raised a question. First thing they usually said was a passive reaction; "They took our water away", and "They poisoned our water". Most of the women were concerned about use of chemicals that may lead to cancer. During my stay, stomach upsets, diarrhoea and eye infections were common among villagers, most probably due to discharge of untreated sewage and solid wastes into the stream from some quarters, which was in fact a conflicting situation while they were complaining about contractor's polluting their water. Some already lost their land. The money paid by the contractor was spent shortly. Since the land was small, they were paid small. Now they are left with nothing. Some try to continue their subsistence by cultivating some relatives' land and share the earnings. Some women seemed to have been psychologically more affected, and obsessively repeated the same thing, e.g. "They took our water away". Even tough it seems unlikely in the near future, potential threat of resettlement makes them very depressed due to a strong feeling of belongingness to Aksu, and anxiety to lose homeland since their living space is, now, a market place.

In conclusion, control of the water is an extension of the control of local people and nature. In Aksu, subsistence agriculture is disappearing and being forced to become a part of the system, accompanied with a vanishing village life and culture. Local people are forced to break from their surrounding nature, and access to their own water is restricted.Discontinuation of a sustainable use and communal management of water putstheir cultural and social life at stake. With increasing number of examples, we see that gains from dams and hydroelectric plants to generate power, supply to urban life, and large scale irrigation projects are at the cost of social, cultural and ecological losses since these water development projects are usually devoid of its social content. In the Aksu Valley, an improperly managed and privatized energy development project, justifying itself for public good have incurred local people to exploitation of all natural and social resources by the private capital. Unfortunately, the state has sacrificed its citizens in favour of global corporate powers. Once there remains no need to remove the stone in front of the ditch to allow flow of water into a land, it is inevitable for all of us to see its reverberation as part of a global hydrosocial circle of waves.

\section{References}

[1] J. Lundquist and P. Gleick, Sustaining Waters into the 21st Century. Background paper to the Comprehensive Assessment of Freshwater Resources of the World, Stockholm: Stockholm Environment Institute (1997).

[2] S.B. Banerjee, C.M.C. Vanessa and M. Raza, The Imperial formations of globalization, in: Organizations, Markets and Imperial Formations: Towards and Anthropology of Globalization, Edward Elgar Publishing, Inc., Cheltenham, 2009, pp.3-16. 
[3] T.C. Lewellen, The Anthropology of Globalization: Cultural Anthropology Enters the 21st Century, Bergin \&Garvey, Westport, 2002.

[4] A.F. Okongwu and J.P. Mencher, The Anthropology of Public Policy: Shifting Terrains, Annual Review of Anthropology, Vol. 29 (2000) 107-127.

[5] C.P. Kottak, The New Ecological Anthropology,in: N. Haenn and R. Wilk(Eds.), The Environment in Anthropology: A Reader in Ecology, Culture and Sustainable Living, New York University Press, New York, 2006, pp. 40-52.

[6] M. Edelman and A. Haugerud, The Antropology of Development and Globalisation, in: M. Edelman and A. Haugerud(Eds.) The Anthropology of Development: From Classical Political Economy and Contemporary Neoliberalism, Blackwell Publishing, Oxford, 2005, pp. 174.

[7] P. Descola and G. Pálsson, Introduction, in: P. Descola and G. Pálsson (Eds.), Nature and Society, Routledge, LondonNew York, edition published in Taylor\&Francis E-Library, 2004, pp. 1-21.

[8] S. Narotzky, The Production of Knowledge and The Production of Hegemony: Anthropological Theory and Political Struggles in Spain, in: G.L. Riberio and A. Escobar (Eds.), World Anthropologies: Disciplinary Formations within Systems of Power, Berg, Oxford and New York, 2006, pp.133-156.

[9] E.J. Nealer and M. Naude, Integrated co-operative governance in the context of sustainable development, TD The Journal for Transdisciplinary Research in Southern Africa, 7(1) July (2011) 105-118.

[10] B. Orlove and S.C. Caton, Water Sustainability: Anthropological Approaches and Prospects, Annual Review of Anthropology, 39 (2010) 401-415.

[11] J. Blatter, H. Ingram and S.L. Levesque, Introduction, in Expanding Perspectives on Transboundary Water in:J. Blatter and H. Ingram (Eds.) Reflections on Water: New Approaches to Transboundary Conflicts and Cooperation, The MIT Press, Massachusetts and London, 2001, pp. 31-53.

[12] S.Sornmani and K. Okanurak, Socioeconomic and health impacts of water resources devleopment in Thailand, in: Brian H. Kay (Ed.)Water Resources: Health, Environment and Development, E\&FN SPON, London and New Yok, 1999, pp. 229-245.

[13] World Commission on Dams. Dams and Development: A New Framework for Decision-Making: The Report of the World Commission on Dams. London and Sterling: Earthscan Publications (2000).

[14] K.A. Berry and E. Mollard, Introduction, in: K.A. Berry and E. Mollard (Eds.) Social Participation in Water Governance and Management: Critical and Global Perspectives, VA: Earthscan, London and Sterling, 2010, pp. xx-xxvii.

[15] V. Strang, The Meaning of Water, Berg, Oxford-New York, 2004.

[16] R.B. Johnston, L. Hiwasaki, I.J. Klaver, A.R. Castillo and V. Strang (Eds.), Water, Cultural Diversity and Global Environmental Change: Emerging Trends, Sustainable Futures,UNESCO and Springer, 2012.
[17] H.G. Brauch, P. Kameri-Mbote, U.O. Spring, N.C. Behera, J. Grin, B. Chorou, C. Mesjasz and H. Krummenacher in:H.G. Brauch (Ed.) Facing Global Environmental Change: Environmental, Human, Energy, Food, Health and Water Security Concepts. Hexagon Series on Human and Enviroment Security and Peace, Vol.4, Springer, Heiderberg, 2009.

[18] TMMOB Su Raporu: Küresel Su Politikalarl ve Türkiye. Ankara, 2009. Information on www.tmmob.org.tr.

[19] F.H. Topçu, Hidroelektrik Santrallarında Kamu ve Özel Sektörün Rolünün Değişimi ve Yarattığ1 Sorunlar, Uluslararası Alanya İşletme Fakültesi Dergisi 3/1 (2011) 223-242.

[20] T. Kaya, Türkiye'de Su Gücü ve Küçük Hidroelektrik Santraller,Nevșehir Üniversitesi Sosyal Bilimler Enstitüsü Dergisi, 1(2011)207:238.

[21] O. Ürker and N. Çobanoğlu, Türkiye'de Hidroelektrik Santrallerin Durumu (HES'ler) ve Cevre Politikaları Bağlamında Değerlendirilmesi, Ankara Üniversitesi Sosyal Bilimler Enstitüsü Dergisi, 3(2) (2012) 65-88.

[22] Information http://www.euas gov.tr/Sayfalar/YillikRaporlar.aspx, access on 15.07.2013

[23] TMMOB Hidroelektrik Santraller Raporu. Ankara, Ekim 2011, Information on www.tmmob.org.tr

[24] M. Hamsici, Dereler ve İsyanlar: "HES, HES, HES! Hadi be sen de! Kes, kes, kes! Beni iyi dinle!, NotaBene Yayınları, Ankara, 2011.

[25] R. Sever and Ö. Ulukalın, Artvin İlinde Yapılan/Yapılmakta Olan Barajlar Hakkında Artvin Halkının Bazı Görüşleri, Doğu Coğrafya Dergisi, 23 (2010) 65-80.

[26] Parallel report in response to the Initial Report by the Republic of Turkey on the Implementation of the International Covenant on Economic, Social and Cultural Rights, submitted on 14 March 2011 by CounterCurrent GegenStrömung to the UN Committe on Economic, Social and Cultural Rights for its 46th Session, 2-20 May (2011).

[27] M. Özalp, O. Kurdoğlu, E.E. Yüksel and S. Yıldırımer, Artvin'de Nehir Tipi Hidroelektrik Santrallerin Olduğu/Olacağı Ekolojik ve Sosyal Sorunlar, Cilt:II. III. Karadeniz Ormancilık Kongresi, 20-22 Mayıs (2010) 677687.

[28] Information on http://www.yesilgazete.org/page/3/?s=Buyuk+Anadolu + Yuruyusu \& $\mathrm{x}=0 \& \mathrm{y}=0$, last access on 17.02.2012

[29] Ö.S. Iș11, Toplumsal Hareket Örneği: HES Karşı1tı Mücadeleler, Sosyolojik Tartışmalar, 3(2012) 8-24.

[30] Information on http://www.necatiaksu.net/aksuvadisi/genel.htm, last access on 17.02.2013.

[31] Information on http://www.borusanenbw.com.tr/en/ProjectAndInvestments/ ExistingPlants.aspx, last access on 17.02.2013.

[32] J. Linton, What is Water? The History of a Modern Abstraction, UBC Press, Vancouver, 2010.

[33] C. Geertz, The Wet and the Dry: Traditional Irrigation in 
Bali and Morocco, Human Ecology, 1 (1972) 34-39.

[34] Information on http://bianet.org/bianet/bianet/125816konser-oncesi-borusan-in-hes-insaatina-protesto, last access on 17.02.2013
[35] E. Swyngedouw, Social Power and the Urbanization of Water: Flows of Power, Oxford University Press, New York, 2004. 